\title{
Dental Appearance- A Survey of Attitudes in Rural and Urban Children
}

\section{Lakshmi PK ${ }^{1}$}

\begin{abstract}
Objective:. The aim of this study was to determine attitude of children towards their dental appearance and to compare same among rural and urban areas of Dakshina Kannada District, Karnataka, India.

Methods: A total population from 2 randomly selected schools (urban-522 and rural- 498) comprising of 1020 children between the age group of $8 y r s-14 y$ rs were provided with questionare containing objective questions to be filled by them . Chi-square test was used to analyze the data. The level of significance was set at $\mathrm{P}<0.05$.

Results: Significant difference was noticed in the attitudes towards their dental appearance among rural and urban children of Dakshina Kannada district $(\mathrm{p}=<0.001)$. Girls were more bothered about esthetics than boys both in rural and urban regions. A definite difference in the attitude was found between rural girls and boys and also between rural and urban boys.
\end{abstract}

Conclusion: Within the limitations of this study it can be concluded that attitudes of children towards their dental appearance differ in rural and urban areas in Dakshina Kannada district, Karnataka, India.

KEYWORDS: Dental appearance, Esthetics, Children

${ }^{1}$ Senior lecturer

Department of Pedodontics

Srinivas Institute of Dental Sciences, Mangalore, Karnataka, India
Contact Author

Dr. Lakshmi Pallavi K pallavi.laksh@gmail.com

J Oral Health Comm Dent 2016;10(2)40-47
INTRODUCTION

7 he appearance of face has an important social and psychological effect on human personality the features most commonly associated with facial appearance are eyes and mouth. The appearance of teeth is related to both cultural factors and individual preferences. Numerous parameters such as the colour, size and align ment of individual teeth in the dental arch are related to esthetics of teeth and individuals facial appearance. The oral region plays an important role when individual speaks or approaches another person. Poor oral hygiene and ugly teeth, for example noticed by others.
Current advertising and media in general emphasize the effect of a pleasant appearance because of its importance in everyday situations (1). Because of exposure of children to many such factors may influence their attitude towards appearance of their face and teeth. The purpose of this study was to determine attitude of children towards their dental appearance and to compare same among rural and urban areas of Dakshina Kannada District, Karnataka, India.

\section{MATERIAL AND METHOD}

A total population from 2 randomly selected schools (urban-522 and rural- 498) comprising of 1020 children between the age group of 8yrs - 14yrs 
were selected. In the study children were provided with a closed ended questionnaire containing objective questions to be filled by them in the local language. Before conducting the survey, permission was obtained from the head of the respective institutions. The basic data was collected using the modified questionnaire based on list of attitudinal statement from a survey by Vallittu et al. (1). Chi-square test was used to analyze the data. The level of significance was set at $\mathrm{P} \leq 0.05$.

\section{RESULTS}

The number of participants in this

\section{QUESTIONNAIRE}

1. Do you think you look good when you smile showing your teeth? Yes/ no

2. Did you feel shy to smile when you lost your front teeth? Yes/no

3. Do you think your newly erupted teeth are big for your face than your milk teeth? Yes/no

4. Do you mind yellow or black spot on your front teeth? Yes /no

5. Is it essential to have regular teeth? Yes/no

6. Does the teeth have great effect on a persons appearance? Yes/no

7. Have you pleased with the appearance of your teeth? Yes/no

8. When your front teeth discolours, or fractures or irregualry arranged or lost what $u$ would do?

a. Go to a dentist as soon as it is noticed.

b. Go to dentist if it pains

\section{Table 1: Comparison Between Rural And Urban Children}

\begin{tabular}{|c|c|c|c|c|}
\hline Questions & Choices & Rural & Urban & $P$ value \\
\hline \multirow[t]{2}{*}{ Smile } & Yes & $\begin{array}{l}369 \\
74.1 \%\end{array}$ & $\begin{array}{l}381 \\
73.0 \%\end{array}$ & 0.688 \\
\hline & No & $\begin{array}{l}129 \\
25.9 \%\end{array}$ & $\begin{array}{l}141 \\
27.0 \%\end{array}$ & \\
\hline \multirow[t]{2}{*}{ Shy } & Yes & $\begin{array}{l}347 \\
69.7 \%\end{array}$ & $\begin{array}{l}413 \\
79.1 \%\end{array}$ & 0.001 \\
\hline & No & $\begin{array}{l}151 \\
30.3 \%\end{array}$ & $\begin{array}{l}109 \\
20.9 \%\end{array}$ & \\
\hline \multirow[t]{2}{*}{ Big teeth } & Yes & $\begin{array}{l}393 \\
78.9 \%\end{array}$ & $\begin{array}{l}467 \\
89.5 \%\end{array}$ & $<0.001$ \\
\hline & No & $\begin{array}{l}105 \\
21.1 \%\end{array}$ & $\begin{array}{l}55 \\
10.5 \%\end{array}$ & \\
\hline \multirow[t]{2}{*}{ Black spot } & Yes & $\begin{array}{l}274 \\
55.0 \%\end{array}$ & $\begin{array}{l}400 \\
76.6 \%\end{array}$ & $<0.001$ \\
\hline & No & $\begin{array}{l}224 \\
45.0 \%\end{array}$ & $\begin{array}{l}122 \\
23.4 \%\end{array}$ & \\
\hline \multirow[t]{2}{*}{ Regular teeth } & Yes & $\begin{array}{l}421 \\
84.5 \%\end{array}$ & $\begin{array}{l}459 \\
87.9 \%\end{array}$ & 0.115 \\
\hline & No & $\begin{array}{l}77 \\
15.5 \%\end{array}$ & $\begin{array}{l}63 \\
12.1 \%\end{array}$ & \\
\hline \multirow[t]{2}{*}{ Persons appearance } & Yes & $\begin{array}{l}328 \\
65.9 \%\end{array}$ & $\begin{array}{l}430 \\
82.4 \%\end{array}$ & $<0.001$ \\
\hline & No & $\begin{array}{l}170 \\
34.1 \%\end{array}$ & $\begin{array}{l}92 \\
17.6 \%\end{array}$ & \\
\hline \multirow[t]{2}{*}{ Pleased with appearance } & Yes & $\begin{array}{l}235 \\
47.2 \%\end{array}$ & $\begin{array}{l}72 \\
13.8 \%\end{array}$ & $<0.001$ \\
\hline & No & $\begin{array}{l}263 \\
52.8 \%\end{array}$ & $\begin{array}{l}450 \\
86.2 \%\end{array}$ & \\
\hline \multirow[t]{2}{*}{ Discoloured or ierrgular teeth } & Go to dentist as soon as noticed & $\begin{array}{l}380 \\
76.3 \%\end{array}$ & $\begin{array}{l}455 \\
87.2 \%\end{array}$ & $<0.001$ \\
\hline & Go to dentist if it pains & $\begin{array}{l}118 \\
23.7 \%\end{array}$ & $\begin{array}{l}67 \\
12.8 \%\end{array}$ & \\
\hline
\end{tabular}


survey included 1020 school children, out of which 522 (51\%) from urban school and 498 (49\%) from rural school. Among urban school children 224 were girls and 298 boys. Among urban school children 213 were girls and 285 boys.

When comparing the rural and urban children regarding their attitude towards the dental appearance majority of the children felt they look good when they smile showing their teeth, no difference between urban and rural set of children. Urban children rela- tively felt more shy to smile when they lost their front teeth $(\mathrm{p}=0.001)$ When asked about the teeth size compared to the size of the face, more of urban children felt that the teeth are larger for the small face compared to rural children and was statistically significant $(p<0.001)$. Regarding the presence of dark spots on teeth, significant number of urban children did not like the spot i.e. they were more conscious than rural children. $\mathrm{p}<0.001$. No statistical difference between urban and rural children about the awareness regarding importantce to have regular teeth $\mathrm{p}=0.115$. More of urban children feel that teeth have great effect on persons appearances compared to rural children $\mathrm{p}<0.001$. Majority of urban children are not pleased with the appearance of their teeth. $\mathrm{p}<0.001$ Urban children go to dentist when they notice the changes in their front teeth, where as the rural children go only when it pains $\mathrm{p}<0.001$ (Table 1).

On comparing boys and girls except for the question regarding the shyness to smile when front tooth was lost, majority of girls said yes and they would

\section{Table 2: Comparison between Boys and Girls}

\begin{tabular}{|c|c|c|c|c|}
\hline Questions & Choices & Boys & Girls & $P$ value \\
\hline \multirow[t]{2}{*}{ smile } & Yes & $\begin{array}{l}379 \\
65.0 \%\end{array}$ & $\begin{array}{l}371 \\
84.9 \%\end{array}$ & $<0.001$ \\
\hline & No & $\begin{array}{l}204 \\
35.0 \%\end{array}$ & $\begin{array}{l}66 \\
15.1 \%\end{array}$ & \\
\hline \multirow[t]{2}{*}{ Shy } & Yes & $\begin{array}{l}430 \\
73.8 \%\end{array}$ & $\begin{array}{l}330 \\
75.5 \%\end{array}$ & 0.524 \\
\hline & No & $\begin{array}{l}153 \\
26.2 \%\end{array}$ & $\begin{array}{l}107 \\
24.5 \%\end{array}$ & \\
\hline \multirow[t]{2}{*}{ Big teeth } & Yes & $\begin{array}{l}462 \\
79.2 \%\end{array}$ & $\begin{array}{l}398 \\
91.1 \%\end{array}$ & $<0.001$ \\
\hline & No & $\begin{array}{l}121 \\
20.8 \%\end{array}$ & $\begin{array}{l}39 \\
8.9 \%\end{array}$ & \\
\hline \multirow[t]{2}{*}{ Black spot } & Yes & $\begin{array}{l}354 \\
60.7 \%\end{array}$ & $\begin{array}{l}320 \\
73.2 \%\end{array}$ & $<0.001$ \\
\hline & No & $\begin{array}{l}229 \\
39.3 \%\end{array}$ & $\begin{array}{l}117 \\
26.8 \%\end{array}$ & \\
\hline \multirow[t]{2}{*}{ Regular teeth } & Yes & $\begin{array}{l}466 \\
79.9 \%\end{array}$ & $\begin{array}{l}414 \\
94.7 \%\end{array}$ & $<0.001$ \\
\hline & No & $\begin{array}{l}117 \\
20.1 \%\end{array}$ & $\begin{array}{l}23 \\
5.3 \%\end{array}$ & \\
\hline \multirow[t]{2}{*}{ Persons appearance } & Yes & $\begin{array}{l}365 \\
62.6 \%\end{array}$ & $\begin{array}{l}393 \\
89.9 \%\end{array}$ & $<0.001$ \\
\hline & No & $\begin{array}{l}218 \\
37.4 \%\end{array}$ & $\begin{array}{l}44 \\
10.1 \%\end{array}$ & \\
\hline \multirow[t]{2}{*}{ Pleased with appearance } & Yes & $\begin{array}{l}233 \\
40.0 \%\end{array}$ & $\begin{array}{l}74 \\
16.9 \%\end{array}$ & $<0.001$ \\
\hline & No & $\begin{array}{l}350 \\
60.0 \%\end{array}$ & $\begin{array}{l}363 \\
83.1 \%\end{array}$ & \\
\hline \multirow[t]{2}{*}{ Discoloured or ierrgular teeth } & Go to dentist as soon as noticed & $\begin{array}{l}435 \\
74.6 \%\end{array}$ & $\begin{array}{l}400 \\
91.5 \%\end{array}$ & $<0.001$ \\
\hline & Go to dentist if it pains & $\begin{array}{l}148 \\
25.4 \%\end{array}$ & $\begin{array}{l}37 \\
8.5 \%\end{array}$ & \\
\hline
\end{tabular}


go to dentist as soon as they notice problem in their front teeth and the difference was statistically significant $\mathrm{p}<0.001$ (Table 2).

On comparing rural boys and girls, both boys and girls felt shy to smile on loosing the front teeth without any statistical difference $\mathrm{p}=0.78$. For all other questions more of girls said yes and difference was statistically significant $\mathrm{p}<0.001$ (Table 3).

When urban boys and girls were compared, more urban girls felt that they look good with teeth shown smile. They also felt teeth have effect on persons appearance and would go to dentist as soon as the problem noticed in the teeth $(p<0.001)$. For other five questions boys and girls answered similarly without statistical difference (Table 4).

On comparing rural and urban boys, both the area boys felt shy to smile when tooth was lost and they felt smiling with teeth shown looks good without statistical difference. For other questions more of urban boys said yes and they were not satisfied with the appearance of their teeth and would go to dentist as soon as the problem noticed and the difference was statistically significant $(p<0.001)$ (Table5).

When rural and urban girls were compared more urban girls felt shy to smile on loosing front teeth $(\mathrm{p}=0.002)$. They also felt it is essential to regular teeth $(\mathrm{p}<0.001)$ and teeth have influence on persons appearance $(p=0.003)$ compared to rural girls and was statistically significant. Other questions were answered similarly by rural and urban

\section{Table 3: Comparison Of Rural Boys And Girls}

\begin{tabular}{|c|c|c|c|c|}
\hline Questions & Choices & Rural boys & Rural girls & $P$ value \\
\hline \multirow[t]{2}{*}{ smile } & Yes & $\begin{array}{l}189 \\
66.3 \%\end{array}$ & $\begin{array}{l}180 \\
84.5 \%\end{array}$ & $<0.001$ \\
\hline & No & $\begin{array}{l}96 \\
33.7 \%\end{array}$ & $\begin{array}{l}33 \\
15.5 \%\end{array}$ & \\
\hline \multirow[t]{2}{*}{ Shy } & Yes & $\begin{array}{l}200 \\
70.2 \%\end{array}$ & $\begin{array}{l}147 \\
69.0 \%\end{array}$ & 0.78 \\
\hline & No & $\begin{array}{l}85 \\
29.8 \%\end{array}$ & $\begin{array}{l}66 \\
31.0 \%\end{array}$ & \\
\hline \multirow[t]{2}{*}{ Big teeth } & Yes & $\begin{array}{l}196 \\
68.8 \%\end{array}$ & $\begin{array}{l}197 \\
92.5 \%\end{array}$ & $<0.001$ \\
\hline & No & $\begin{array}{l}89 \\
31.2 \%\end{array}$ & $\begin{array}{l}16 \\
7.5 \%\end{array}$ & \\
\hline \multirow[t]{2}{*}{ Black spot } & Yes & $\begin{array}{l}120 \\
42.1 \%\end{array}$ & $\begin{array}{l}154 \\
72.3 \%\end{array}$ & $<0.001$ \\
\hline & No & $\begin{array}{l}165 \\
57.9 \%\end{array}$ & $\begin{array}{l}59 \\
27.7 \%\end{array}$ & \\
\hline \multirow[t]{2}{*}{ Regular teeth } & Yes & $\begin{array}{l}210 \\
73.7 \%\end{array}$ & $\begin{array}{l}211 \\
99.1 \%\end{array}$ & $<0.001$ \\
\hline & No & $\begin{array}{l}75 \\
26.3 \%\end{array}$ & $\begin{array}{l}2 \\
0.9 \%\end{array}$ & \\
\hline \multirow[t]{2}{*}{ Persons appearance } & Yes & $\begin{array}{l}145 \\
50.9 \%\end{array}$ & $\begin{array}{l}183 \\
85.9 \%\end{array}$ & $<0.001$ \\
\hline & No & $\begin{array}{l}140 \\
49.1 \%\end{array}$ & $\begin{array}{l}30 \\
14.1 \%\end{array}$ & \\
\hline \multirow[t]{2}{*}{ Pleased with appearance } & Yes & $\begin{array}{l}195 \\
68.4 \%\end{array}$ & $\begin{array}{l}40 \\
18.8 \%\end{array}$ & $<0.001$ \\
\hline & No & $\begin{array}{l}90 \\
31.6 \%\end{array}$ & $\begin{array}{l}173 \\
81.2 \%\end{array}$ & \\
\hline \multirow[t]{2}{*}{ Discoloured or ierrgular teeth } & Go to dentist as soon as noticed & $\begin{array}{l}190 \\
66.7 \%\end{array}$ & $\begin{array}{l}190 \\
89.2 \%\end{array}$ & $<0.001$ \\
\hline & Go to dentist if it pains & $\begin{array}{l}95 \\
33.3 \%\end{array}$ & $\begin{array}{l}23 \\
10.8 \%\end{array}$ & \\
\hline
\end{tabular}


girls without any statistically significant difference (Table 6).

\section{DISCUSSION}

Physical appearance, including the dentition, is an important aspect of human activity, as one aims to be liked, respected or accepted by those around $\mathrm{him} / \mathrm{her}$. The uptake of dental esthetic treatment is influenced by the desire to look attractive, the self-perception of dental appearance, self-esteem, gender, age and peer group norms $(2,3)$. Patients attitudes toward orthododntic treatment has been examined in several studies $(4,5)$. A study by Bos et al. (4) examined school children's attitude toward dental appearance. He concluded that although attractive teeth are highly valued in general children give priority to other issues in their lives. Studies examining Chidren's attitude toward their dental appearance are very few in India and there is a need to know the views of both rural and urban people because majority of population resides in rural areas in India.

The schools which formed the part of the survey were belonging to both rural and urban area of Dakshina Kannada district. The age group 8-14 years was selected as they involve both preadolescents and adolescents. The urban school selected was located in the heart of the Mangalore city. Rural school was $30 \mathrm{~km}$ from the Mangalore city. The questionnaire was prepared with some basic questions which could test the attitude and knowledge of children towards dental appearance.

On asking about whether they look good with teeth shown smile majority of children say yes and no differ-

\section{Table 4: Comparison of urban boys and girls}

\begin{tabular}{|c|c|c|c|c|}
\hline Questions & Choices & Rural girls & Urban girls & $P$ value \\
\hline \multirow[t]{2}{*}{ Smile } & Yes & $\begin{array}{l}190 \\
63.8 \%\end{array}$ & $\begin{array}{l}191 \\
85.3 \%\end{array}$ & $<0.001$ \\
\hline & No & $\begin{array}{l}108 \\
36.2 \%\end{array}$ & $\begin{array}{l}33 \\
14.7 \%\end{array}$ & \\
\hline \multirow[t]{2}{*}{ Shy } & Yes & $\begin{array}{l}230 \\
77.2 \%\end{array}$ & $\begin{array}{l}183 \\
81.7 \%\end{array}$ & 0.209 \\
\hline & No & $\begin{array}{l}68 \\
22.8 \%\end{array}$ & $\begin{array}{l}41 \\
18.3 \%\end{array}$ & \\
\hline \multirow[t]{2}{*}{ Big teeth } & Yes & $\begin{array}{l}266 \\
89.3 \%\end{array}$ & $\begin{array}{l}201 \\
89.7 \%\end{array}$ & 0.862 \\
\hline & No & $\begin{array}{l}32 \\
10.7 \%\end{array}$ & $\begin{array}{l}23 \\
10.3 \%\end{array}$ & \\
\hline \multirow[t]{2}{*}{ Black spot } & Yes & $\begin{array}{l}234 \\
78.5 \%\end{array}$ & $\begin{array}{l}166 \\
74.1 \%\end{array}$ & 0.238 \\
\hline & No & $\begin{array}{l}64 \\
21.5 \%\end{array}$ & $\begin{array}{l}58 \\
25.9 \%\end{array}$ & \\
\hline \multirow[t]{2}{*}{ Regular teeth } & Yes & $\begin{array}{l}256 \\
85.9 \%\end{array}$ & $\begin{array}{l}203 \\
90.6 \%\end{array}$ & 0.101 \\
\hline & No & $\begin{array}{l}42 \\
14.1 \%\end{array}$ & $\begin{array}{l}21 \\
9.4 \%\end{array}$ & \\
\hline \multirow[t]{2}{*}{ Persons appearance } & Yes & $\begin{array}{l}220 \\
73.8 \%\end{array}$ & $\begin{array}{l}210 \\
93.8 \%\end{array}$ & $<0.001$ \\
\hline & No & $\begin{array}{l}78 \\
26.2 \%\end{array}$ & $\begin{array}{l}14 \\
6.3 \%\end{array}$ & \\
\hline \multirow[t]{2}{*}{ Pleased with appearance } & Yes & $\begin{array}{l}38 \\
12.8 \%\end{array}$ & $\begin{array}{l}34 \\
15.2 \%\end{array}$ & 0.426 \\
\hline & No & $\begin{array}{l}260 \\
87.2 \%\end{array}$ & $\begin{array}{l}190 \\
84.8 \%\end{array}$ & \\
\hline \multirow[t]{2}{*}{ Discoloured or ierrgular teeth } & Go to dentist as soon as noticed & $\begin{array}{l}245 \\
82.2 \%\end{array}$ & $\begin{array}{l}210 \\
93.8 \%\end{array}$ & $<0.001$ \\
\hline & Go to dentist if it pains & $\begin{array}{l}53 \\
17.8 \%\end{array}$ & $\begin{array}{l}14 \\
6.3 \%\end{array}$ & \\
\hline
\end{tabular}


ence between urban and rural set of people. More urban children (79.1\%) felt shy to smile when they lost their front teeth compared to rural children (69.7\%). More urban children feel the new teeth are big for their face. Urban children don't like the yellow or black spot more than rural children, i.e. they are more conscious and is statistically significant. Both urban and rural children are aware that it is important to have regular teeth, no statistical difference between them. In a study by Emeria at al (6) in Tanzania most children $(85 \%)$ recognized the importance of well-aligned teeth for overall facial appearance. Urban children strongly feel that teeth influence the appearance of a person more than the rural children. Majority of Urban children were not satisfied with the appearance of their teeth and most of them would like to go to dentist as soon as the find any problem like color change, malalignment, fracture etc, whereas most of the rural children prefer going to dentist if only when tooth pains. There was statistical difference between the answers given by rural and urban children which reflect the comparative- ly negative attitude of rural children toward dental appearance. This may be due lack of awareness programs in rural area both for children and their parents. In a study by Elham et al. (7) Rural and urban school children did not differ in the perception of their own dentition but more urban than rural students wanted to have their teeth straightened.

There was gender difference noticed about their attitude towards dental appearance and was statistically significant. Boys were comparatively less

\section{Table 5: Comparison of rural and urban boys}

\begin{tabular}{|c|c|c|c|c|}
\hline Questions & Choices & Rural boys & Urban boys & $P$ value \\
\hline \multirow[t]{2}{*}{ Smile } & Yes & $\begin{array}{l}189 \\
66.3 \%\end{array}$ & $\begin{array}{l}190 \\
63.8 \%\end{array}$ & 0.518 \\
\hline & No & $\begin{array}{l}96 \\
33.7 \%\end{array}$ & $\begin{array}{l}108 \\
36.2 \%\end{array}$ & \\
\hline \multirow[t]{2}{*}{ Shy } & Yes & $\begin{array}{l}200 \\
70.2 \%\end{array}$ & $\begin{array}{l}230 \\
77.2 \%\end{array}$ & 0.055 \\
\hline & No & $\begin{array}{l}85 \\
29.8 \%\end{array}$ & $\begin{array}{l}68 \\
22.8 \%\end{array}$ & \\
\hline \multirow[t]{2}{*}{ Big teeth } & Yes & $\begin{array}{l}196 \\
68.8 \%\end{array}$ & $\begin{array}{l}266 \\
89.3 \%\end{array}$ & $<0.001$ \\
\hline & No & $\begin{array}{l}89 \\
31.2 \%\end{array}$ & $\begin{array}{l}32 \\
10.7 \%\end{array}$ & \\
\hline \multirow[t]{2}{*}{ Black spot } & Yes & $\begin{array}{l}120 \\
42.1 \%\end{array}$ & $\begin{array}{l}234 \\
78.5 \%\end{array}$ & $<0.001$ \\
\hline & No & $\begin{array}{l}165 \\
57.9 \%\end{array}$ & $\begin{array}{l}64 \\
21.5 \%\end{array}$ & \\
\hline \multirow[t]{2}{*}{ Regular teeth } & Yes & $\begin{array}{l}210 \\
73.7 \%\end{array}$ & $\begin{array}{l}256 \\
85.9 \%\end{array}$ & $<0.001$ \\
\hline & No & $\begin{array}{l}75 \\
26.3 \%\end{array}$ & $\begin{array}{l}42 \\
14.1 \%\end{array}$ & \\
\hline \multirow[t]{2}{*}{ Persons appearance } & Yes & $\begin{array}{l}145 \\
50.9 \%\end{array}$ & $\begin{array}{l}220 \\
73.8 \%\end{array}$ & $<0.001$ \\
\hline & No & $\begin{array}{l}140 \\
49.1 \%\end{array}$ & $\begin{array}{l}78 \\
26.2 \%\end{array}$ & \\
\hline \multirow[t]{2}{*}{ Pleased with appearance } & Yes & $\begin{array}{l}195 \\
68.4 \%\end{array}$ & $\begin{array}{l}38 \\
12.8 \%\end{array}$ & $<0.001$ \\
\hline & No & $\begin{array}{l}90 \\
31.6 \%\end{array}$ & $\begin{array}{l}260 \\
87.2 \%\end{array}$ & \\
\hline \multirow[t]{2}{*}{ Discoloured or ierrgular teeth } & Go to dentist as soon as noticed & $\begin{array}{l}190 \\
66.7 \%\end{array}$ & $\begin{array}{l}245 \\
82.2 \%\end{array}$ & $<0.001$ \\
\hline & Go to dentist if it pains & $\begin{array}{l}95 \\
33.3 \%\end{array}$ & $\begin{array}{l}53 \\
17.8 \%\end{array}$ & \\
\hline
\end{tabular}


bothered regarding their teeth than girls and they were pleased with the appearance of teeth and less concerned about regular alignment of teeth and does not believe much that teeth have effect on persons appearance. Among the rural children also similar result obtained for boys and girls. A study by Elham et al. (7) concluded that there is gender difference in self perception of malocclusion and females are more willing to have orthodontic treatment. The difference in opinion about dental appearance between boys and girls may be due to inherent beauty conscious- ness in girls.

When urban boys and girls were compared, their view was almost same about the dental appearance except that more of girls preferred smiling with teeth shown and felt that teeth do have effect on persons appearance. They also preferred to visit dentist as soon as the problem is noticed. The lack of gender variation for most of the questions may be due to awareness by media, school health education programs and parental attitude, which may be responsible for more awareness among boys. A study conducted in Dutch school also showed no gender difference in attitude towards dental appearance (8).

The difference in rural boys and girls may be due to natural tendency of girls to think more about their facial esthetics and with lack of influence of parents. This is also reflected in attitudes of rural and urban boys; urban boys were more aware of importance of role of teeth in esthetics which may be due to parental influence and media influence.

Table 6: Comparison of rural and urban girls

\begin{tabular}{|c|c|c|c|c|}
\hline Questions & Choices & Rural girls & Urban girls & $P$ value \\
\hline \multirow[t]{2}{*}{ Smile } & Yes & $\begin{array}{l}180 \\
84.5 \%\end{array}$ & $\begin{array}{l}191 \\
85.3 \%\end{array}$ & 0.824 \\
\hline & No & $\begin{array}{l}33 \\
15.5 \%\end{array}$ & $\begin{array}{l}33 \\
14.7 \%\end{array}$ & \\
\hline \multirow[t]{2}{*}{ Shy } & Yes & $\begin{array}{l}147 \\
69.0 \%\end{array}$ & $\begin{array}{l}183 \\
81.7 \%\end{array}$ & 0.002 \\
\hline & No & $\begin{array}{l}66 \\
31.0 \%\end{array}$ & $\begin{array}{l}41 \\
18.3 \%\end{array}$ & \\
\hline \multirow[t]{2}{*}{ Big teeth } & Yes & $\begin{array}{l}197 \\
92.5 \%\end{array}$ & $\begin{array}{l}201 \\
89.7 \%\end{array}$ & 0.312 \\
\hline & No & $\begin{array}{l}16 \\
7.5 \%\end{array}$ & $\begin{array}{l}23 \\
10.3 \%\end{array}$ & \\
\hline \multirow[t]{2}{*}{ Black spot } & Yes & $\begin{array}{l}154 \\
72.3 \%\end{array}$ & $\begin{array}{l}166 \\
74.1 \%\end{array}$ & 0.670 \\
\hline & No & $\begin{array}{l}59 \\
27.7 \%\end{array}$ & $\begin{array}{l}58 \\
25.9 \%\end{array}$ & \\
\hline \multirow[t]{2}{*}{ Regular teeth } & Yes & $\begin{array}{l}211 \\
99.1 \%\end{array}$ & $\begin{array}{l}203 \\
90.6 \%\end{array}$ & $<0.001$ \\
\hline & No & $\begin{array}{l}2 \\
.9 \%\end{array}$ & $\begin{array}{l}21 \\
9.4 \%\end{array}$ & \\
\hline \multirow[t]{2}{*}{ Persons appearance } & Yes & $\begin{array}{l}183 \\
85.9 \%\end{array}$ & $\begin{array}{l}210 \\
93.8 \%\end{array}$ & 0.003 \\
\hline & No & $\begin{array}{l}30 \\
14.1 \%\end{array}$ & $\begin{array}{l}14 \\
6.3 \%\end{array}$ & \\
\hline \multirow[t]{2}{*}{ Pleased with appearance } & Yes & $\begin{array}{l}40 \\
18.8 \%\end{array}$ & $\begin{array}{l}34 \\
15.2 \%\end{array}$ & 0.316 \\
\hline & No & $\begin{array}{l}173 \\
81.2 \%\end{array}$ & $\begin{array}{l}190 \\
84.8 \%\end{array}$ & \\
\hline \multirow[t]{2}{*}{ Discoloured or ierrgular teeth } & Go to dentist as soon as noticed & $\begin{array}{l}190 \\
89.2 \%\end{array}$ & $\begin{array}{l}210 \\
93.8 \%\end{array}$ & 0.088 \\
\hline & Go to dentist if it pains & $\begin{array}{l}23 \\
10.8 \%\end{array}$ & $\begin{array}{l}14 \\
6.3 \%\end{array}$ & \\
\hline
\end{tabular}


Involving parents in the survey would have been better to know what they think about their children dental appearance, also parents are the main decision makers to provide their children with good dental care as the parents opinion is important in Indian scenario. Recruiting of a larger sample size and open ended questionnaire would have made this survey more interesting.

\section{CONCLUSION}

Significant difference was noticed in the attitude of the children regarding their dental appearance among rural and urban region of Dakshina Kannada district. Role of both print and electronic media in creating this awareness is tremendous in urban set up. Girls were more bothered about esthetics. A definite difference in the attitude was found between rural girls and boys, and rural and urban boys.

\section{REFERENCES}

1. P.K Vallittu, A.S. J. Vallittu and V. P. Lassila. Dental esthetics- a survey of attitudes in different groups of patients. $J$ Dent 1996;24:335-38.

2. Shaw WC. The influence of children,s dentofacial appearance on their social attractiveness as judged by peers and adults. Am J Orthod 1981;79:399-415.

3. Burden DJ. The infl uence of social class, gender and peers on the uptake of orthodontic treatment. European Journal of Orthodontics 1995;17:199-203.

4. Bos A, Hoogstraten J, Prahl-Andersen B. Attitudes toward orthododntic treatment. A comparison of treated and untreated subjects. Eur J Orthod 2005;27:148-54.

5. Stenvik A, Espeland L, Linge BO, Ling L. Lay attitudes to dental appearance and need for orthodontic treatment. Eur $J$ Orthod 1997;19:271-77.

6. Emeria A. Mugonzibwa, Anne M. Kuijpers-Jagtman, Martin A. Van 't Hof, Emil N. Kikwilu. Perceptions of dental attractiveness and orthodontic treatment need among Tanzanian children. Am J Orthod Dentofacial Orthop 2004;125:42634

7. Elham SJ. Abu Alhaija, Kazem S. Al-Nimri and Susan N. Al-Khateeb. Self-perception of malocclusion among north Jordanian school children. European Journal of Orthodontics 2005:27:292-95.

8. Annemieke Bos, Johan Hoogstraten, Birte Prahl- Andersen. Dutch primary school children attitudes toward their dental appearance. Pediatr Dent 2008;30:43942. 